\title{
NMDA Receptor-Dependent LTD Is Required for Consolidation But Not Acquisition of Fear Memory
}

\author{
Xing Liu, ${ }^{1,2 *}$ Qin-Hua Gu, ${ }^{1 *}$ Kaizheng Duan, ${ }^{1 *}$ and Zheng Li $^{1}$ \\ ${ }^{1}$ Unit on Synapse Development and Plasticity, National Institute of Mental Health, National Institutes of Health, Bethesda, Maryland 20892, and ${ }^{2} T h e$ State \\ Key Laboratory of Medical Neurobiology and Pharmacology Research Center, Shanghai Medical College and Institutes of Brain Science, Fudan University, \\ Shanghai 200032, People's Republic of China
}

\begin{abstract}
NMDA receptor-dependent long-term depression (NMDAR-LTD) is a form of synaptic plasticity leading to long-lasting decreases in synaptic strength. NMDAR-LTD is essential for spatial and working memory, but its role in hippocampus-dependent fear memory has yet to be determined. Induction of NMDAR-LTD requires the activation of caspase-3 by cytochrome $c$. Cytochrome $c$ normally resides in mitochondria and during NMDAR-LTD is released from mitochondria, a process promoted by Bax (Bcl-2-associated X protein). Bax induces cell death in apoptosis, but it plays a nonapoptotic role in NMDAR-LTD. Here, we investigated the role of NMDAR-LTD in fear memory in CA1-specific Bax knock-out mice. In hippocampal slices from these knock-out mice, while long-term potentiation of synaptic transmission, basal synaptic transmission, and paired-pulse ratio are intact, LTD in both young and fear-conditioned adult mice is obliterated. Interestingly, in CA1-specific Bax knock-out mice, long-term contextual fear memory is impaired, but the acquisition of fear memory and innate fear are normal. Moreover, these conditional Bax knock-out mice exhibit less behavioral despair. These findings indicate that NMDAR-LTD is required for consolidation, but not the acquisition of fear memory. Our study also shows that Bax plays an important role in depressive behavior.
\end{abstract}

Key words: Bax; NMDA receptor; LTD; memory consolidation; fear memory; depressive behavior

\section{Introduction}

NMDA receptor-dependent long-term depression (NMDARLTD) of synaptic transmission (Bear and Malenka, 1994), characterized by a long-lasting decrease in synaptic strength, is a form of synaptic plasticity essential for the refinement of neuronal connections during development and information storage in the brain (Collingridge et al., 2010). NMDAR-LTD is widely expressed in excitatory synapses of the CNS (Malenka and Bear, 2004). The induction of NMDAR-LTD requires the opening of NMDA receptors, which leads to $\mathrm{Ca}^{2+}$ influx and subsequent activation of the serine/threonine phosphatases calcineurin/ PP2B and PP1. These protein phosphatases in turn cause dephosphorylation and translocation of Bad (Bcl-2-associated agonist of cell death) to mitochondria, where it activates Bax (Bcl-2associated X protein; Xin and Deng, 2006).

Bax is a member of the Bcl-2 family proteins that form pores in mitochondrial membranes, through which cytochrome $c$ (a mitochondrial resident protein) is released into the cytosol

\footnotetext{
Received June 27, 2013; revised April 21, 2014; accepted April 23, 2014

Author contributions: Z.L. designed research; X.L., Q.-H.G., and K.D. performed research; X.L., Q.-H.G., and K.D. analyzed data; X.L. and Z.L. wrote the paper.

This work was supported by the National Institute of Mental Health, Division of Intramural Research Programs, National Institutes of Health.

The authors declare no competing financial interests.

*X.L., Q.-H.G., and K.D. contributed equally to this work.

Correspondence should be addressed to Zheng Li, National Institute of Mental Health, National Institutes of Health, 35 Convent Drive, Room 2C1010, Bethesda, MD 20892-3732. E-mail: lizheng2@mail.nih.gov.

DOI:10.1523/JNEUROSCI.2752-13.2014

Copyright $\odot 2014$ the authors $\quad 0270-6474 / 14 / 348741-08 \$ 15.00 / 0$
}

(Wolter et al., 1997). During apoptosis, mitochondrial release of cytochrome $c$ triggers caspase 3 activation, thereby inducing cell death (Oltvai et al., 1993). In LTD, unlike in apoptosis, however, Bax is, and so is caspase- 3 , activated only moderately and transiently; therefore, LTD, but not cell death, is induced (Li et al., 2010; Jiao and $\mathrm{Li}, 2011)$. This Bax-caspase- 3 cascade is required specifically for NMDAR-LTD. In Bax knock-out (KO) mice, NMDAR-LTD is abolished, while long-term potentiation (LTP) is preserved (Jiao and Li, 2011).

Bax has been implicated in the pathophysiology of psychiatric disorders such as depression (Manji et al., 2012). For instance, the $\mathrm{Bax} / \mathrm{Bcl}-2$ ratio in the brain is increased by chronic stress (e.g., social isolation) and is reduced by chronic treatment with the antidepressant fluoxetine (Djordjevic et al., 2012; Zlatković and Filipović, 2012). The role played by Bax in depression, however, is unclear and is thought to be related to its proapoptotic function.

The hippocampus plays an important role in learning and memory (Teyler and Rudy, 2007; Rudy and Sutherland, 2008). For instance, LTD impairment in CA1 neurons caused by genetic deletion of NMDA receptor subunits or signaling molecules required for LTD (such as GluN2B and PI3K $\gamma$ ) is associated with deficits in hippocampus-dependent spatial and working memory (Wong et al., 2007; Nicholls et al., 2008; Brigman et al., 2010; Kim et al., 2011). The role played by NMDAR-LTD in hippocampusdependent fear memory, however, remains elusive.

In this study, we investigated the role of NMDAR-LTD in fear memory in conditional Bax knock-out mice in which Bax expression is deleted in CA1 pyramidal neurons. Our electrophysiology 
results show that NMDAR-LTD (but not LTP) is abolished in young and fearconditioned adult knock-out mice. Behavioral tests reveal that, in conditional Bax knock-out mice, while innate fear, short-term contextual fear memory, and cued fear memory are intact, longterm contextual fear memory is impaired. Depressive behavior, moreover, is also attenuated in CA1-specific Bax knock-out mice. These findings indicate that NMDAR-LTD and Bax are required specifically for consolidation of, but not acquisition of, fear memory.

\section{Materials and Methods}

\section{Knock-out mice}

The floxed $\operatorname{Bax}\left(\operatorname{Bax}^{\mathrm{fl} /+}\right)$ and the CA1-specific Cre (T29-1) mouse lines were purchased from The Jackson Laboratory. Bax ${ }^{\mathrm{f} /+}$ mice were generated in the Stanley J. Korsmeyer laboratory (Howard Hughes Medical Institute, Yale University School of Medicine, New Haven, CT) by inserting loxP sites to flank exons $2-4$, as described previously (Takeuchi et al., 2005).

The T29-1 transgenic mice express Cre recom-

binase under the control of a promoter derived from the mouse calcium/ calmodulin-dependent protein kinase II $\alpha$ gene (Tsien et al., 1996a). We crossed the $\mathrm{Bax}^{\mathrm{fl} /+}$ and the T29-1 lines to obtain conditional Bax knockout mice that have exons 2-4 of the Bax gene deleted primarily in CA1 pyramidal cells. All mouse work in this study complies with the Guide for the Care and Use of Laboratory Animals of the National Institutes of Health, and was approved by the Animal Care and Use Committee of the National Institute of Mental Health (Animal Study Proposal \#GCP-02).

\section{Behavioral tests}

Animals were maintained under a $12 \mathrm{~h}$ light/dark cycle in a temperaturecontrolled $\left(22 \pm 2^{\circ} \mathrm{C}\right)$ and humidity-controlled $(50 \pm 5 \%)$ environment. Male Bax knock-out and wild-type (WT) littermates, 8 to 10 weeks of age, were used for all behavioral tests. Behavioral tests were conducted in a soundproofed behavioral room during the light cycle of the animal.

Open field. Mice were placed in the center of an open-field test chamber (gray, $40 \times 40 \times 40 \mathrm{~cm}$ ) and were allowed to freely explore the arena for $30 \mathrm{~min}$. The movement of the mice was videotaped and analyzed using HomeCageScan Software (CleverSys).

Light/dark box. The light/dark box $(46 \times 27 \times 30 \mathrm{~cm})$ is composed of two compartments: the dark compartment (one third of the box) and the light compartment (two thirds of the box). Mice were placed in the center of the light box and then monitored for $6 \mathrm{~min}$. The time mice spent in each compartment was analyzed with Clever System software (CleverSys).

Elevated zero maze. The track ( $9 \mathrm{~cm}$ wide) of the elevated zero maze (60 $\mathrm{cm}$ in diameter; CleverSys) is divided into four equal sections. Two opposing sections are left open, and the other two sections are enclosed by two $15-\mathrm{cm}$-tall walls. The room was illuminated with 25 lux ambient light during the test. Mice were placed in the middle of one open section to begin the test and were left on the maze for $6 \mathrm{~min}$. The time mice spent in each section was analyzed with Clever System software (CleverSys).

Tail suspension test. Mice were suspended by the tip of the tail with tape from a horizontal bar and were positioned such that the base of their tails was vertical to the bottom of the bar. Each test lasted $6 \mathrm{~min}$. Immobility was analyzed with the TailSuspension Software (CleverSys).

Forced swimming test. Mice were gently released into a transparent Plexiglas cylinder ( $40 \mathrm{~cm}$ in height, $26 \mathrm{~cm}$ in diameter) filled with water $\left(24 \pm 1{ }^{\circ} \mathrm{C}, 20 \mathrm{~cm}\right.$ high) for a $6 \mathrm{~min}$ session (under $<500$ lux ambient light). Immobility (i.e., cessation of limb movement except minor involuntary movement of the hind limbs) was scored with the ForcedSwimScan software (CleverSys).
Fear conditioning. On day 1 , mice were allowed to explore the test chamber (Med Associates) for $2 \mathrm{~min}$. On day 2, the mouse was placed in the same test chamber for $2 \mathrm{~min}$, then exposed to the conditioned stimulus (CS; a $2800 \mathrm{~Hz}, 85 \mathrm{~dB}$ tone lasting for $30 \mathrm{~s}$ ) coterminated with the unconditioned stimulus (1.0 mA of continuous $1 \mathrm{~s}$ footshock). At $30 \mathrm{~s}$ after the footshock, the mouse was returned to its home cage. To test for contextual fear memory, at 1 or $24 \mathrm{~h}$ after training mice were placed in the training chamber and monitored for $3 \mathrm{~min}$. To test for cue fear memory, at 1 or $24 \mathrm{~h}$ after training mice were placed in a novel chamber, and exposed to $\mathrm{CS}$ at $3 \mathrm{~min}$ after they were introduced into the chamber. Freezing was defined as the complete immobility of the animal, except for respiratory movement. Different cohorts of animals were used for each type of memory test, and each animal underwent only one type of memory test.

\section{Electrophysiology}

Hippocampal slices were prepare and electrophysiology were conducted as described previously (Jiao and Li, 2011). Briefly, mice [postnatal day 17 (P17)-P20 or 7-9 weeks old] were anesthetized by isoflurane overdose followed by decapitation. The brain was placed in ice-cold artificial CSF (ACSF), pH 7.4 (gassed with $95 \% \mathrm{O}_{2} / 5 \% \mathrm{CO}_{2}$ ), which is composed of the following (in mM): $124 \mathrm{NaCl}, 3 \mathrm{KCl}, 26 \mathrm{NaHCO}_{3}, 1.25 \mathrm{NaH}_{2} \mathrm{PO}_{4}, 2.5$ $\mathrm{CaCl}_{2}, 1.3 \mathrm{MgSO}_{4}$, and $10 \mathrm{D}$-glucose. Transverse hippocampal slices (350 $\mu \mathrm{m}$ for P17-P20 and $450 \mu \mathrm{m}$ for 7- to 9-week-old mice) were prepared in ice-chilled oxygenated ACSF with a vibratome (Leica). Hippocampal slices were recovered in ACSF (bubbled with $95 \% \mathrm{O}_{2} / 5 \% \mathrm{CO}_{2}$ at $30^{\circ} \mathrm{C}$ ) at $30^{\circ} \mathrm{C}$ for $30 \mathrm{~min}$, then at room temperature for $30 \mathrm{~min}$ before being transferred to the recording chamber. Hippocampal slices were perfused with ACSF at the rate of $2 \mathrm{ml} / \mathrm{min}$ during recording. The stimulating electrode was placed on the stratum radiatum in the CA2 area. Recording pipettes (1-2 $\mathrm{M} \Omega$ ) were filled with the bath solution and placed in the CA1 region. LTD was induced by low-frequency stimulations ( 900 pulses at $1 \mathrm{~Hz}$ ).

\section{Histology}

Mice were transcardially perfused with PBS, followed by fixative (4\% paraformaldehyde in PBS). Brains were removed, post-fixed in the same fixative overnight, and then transferred to $30 \%$ sucrose in fixative. Coronal brain sections $(20 \mu \mathrm{m})$ were cut with a cryostat (Leica). For terminal deoxynucleotidyl transferase-mediated biotinylated UTP nick end labeling (TUNEL), the DeadEnd Fluorometric TUNEL Kit (G3250; Promega) was used following the manufacturer's instructions. Brain sections were mounted in $4^{\prime}, 6^{\prime}$-diamidino-2-phenylindole dihydrochloride (DAPI)containing mounting medium $(1.5 \mu \mathrm{g} / \mathrm{ml} ; \mathrm{H}-1500$, Vector Laboratories) after TUNEL. Stained sections were examined at $63 \times$ (numerical aperture, 
A
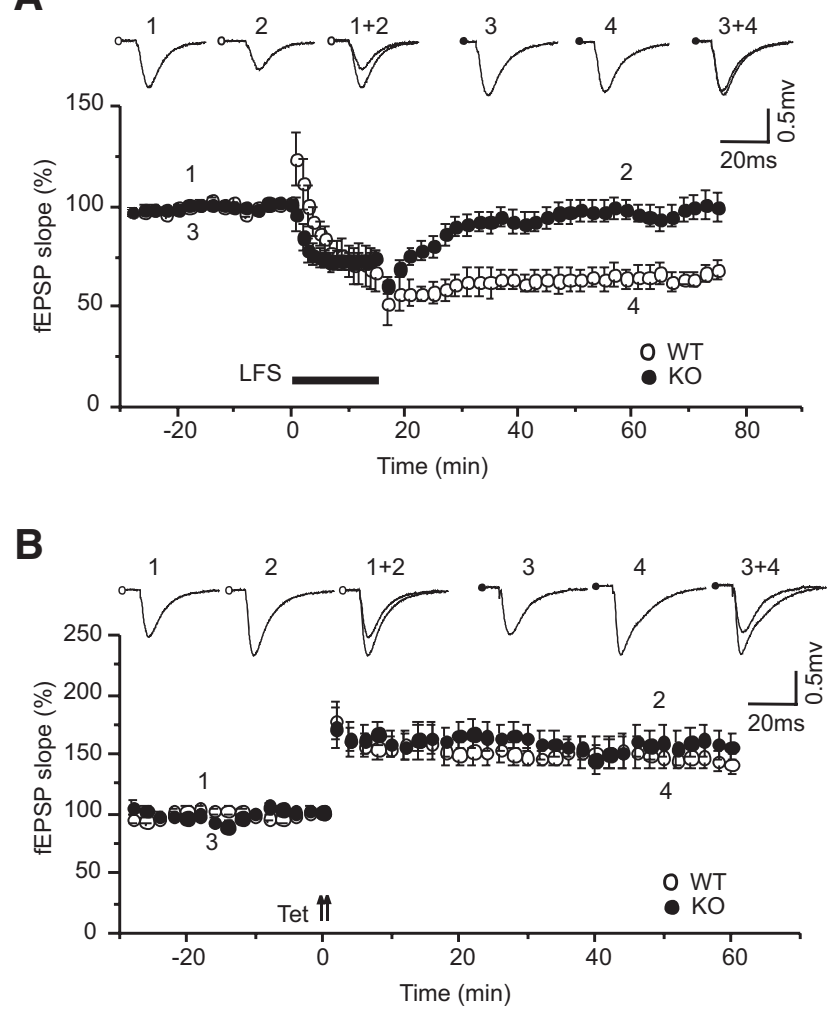

Figure 2. LTD is impaired, and LTP is intact in CA1-specific Bax knock-out mice. Hippocampal slices were prepared from CA1-specific Bax knock-out mice and their wild-type littermates (P17-P20). fEPSP elicited by stimulating the Schaffer collateral pathway was recorded in the CA1 region. $A$, LTD induced by low-frequency stimulation ( $1 \mathrm{~Hz}, 900$ pulses). $n=7$ slices from four wild-type and $n=8$ slices from five knock-out mice. $B$, LTP induced by two tetanic stimulations ( $100 \mathrm{~Hz}, 1 \mathrm{~s}$ ). $n=6$ slices from four wild-type mice; $n=6$ slices from four knock-out mice. Data are presented as the mean \pm SEM.

1.4) with a Zeiss LSM 510 confocal microscope. To assess the cell number, TUNEL- and DAPI-positive cells in the CA1 region from the brightest stack of confocal images were counted manually. Three to five sections from each animal and five animals for each condition were analyzed.

\section{Immunohistochemistry}

The conditional Bax knock-out mice and their wild-type littermates ( $7 \mathrm{~d}$, $20 \mathrm{~d}$, and 12 weeks of age) were perfused and fixed, and the brains were cut into sections as described in the Histology section. Brain sections were permeabilized with $0.5 \%$ Triton X-100 (in PBS) for $1 \mathrm{~h}$ at room temperature, blocked for $2 \mathrm{~h}$ at room temperature in blocking solution (5\% goat serum, $0.5 \%$ Tween 20 in PBS), and then incubated with the anti-Bax antibody (diluted 1:100 in blocking solution; sc-7480, Santa Cruz Biotechnology) at $4^{\circ} \mathrm{C}$ for $48 \mathrm{~h}$. After rinsing with PBS (0.5\% Tween 20 , four times, 10 min each time), sections were incubated with an Alexa Fluor 555conjugated secondary antibody (diluted 1:100 in PBS; A-21424, Invitrogen) for $1 \mathrm{~h}$ at room temperature. The sections were washed four times in PBS (10 min each time) and then were mounted in mounting medium (containing $1.5 \mu \mathrm{g} / \mathrm{ml}$ DAPI; H-1500, Vector Laboratories). Images were acquired with a Zeiss LSM 510 confocal microscope $(10 \times)$.

\section{Data analysis}

Data were analyzed with Kolmogorov-Smirnov test for distribution. To calculate $p$ values, a two-tailed Student's $t$ test was used for normally distributed data, and a two-way ANOVA (lineal model) followed by post hoc Tukey tests or Kruskal-Wallis one-way ANOVA on ranks were used for non-normally distributed data of behavioral tests. The electrophysiological data were analyzed with one-way ANOVA followed by post hoc Fisher's tests for normally distributed data, and Kruskal-Wallis one-way ANOVA on ranks for non-normally distributed data.

\section{Results}

LTD is impaired in CA1-specific Bax knock-out mice

Since the number of neurons in constitutive Bax knock-out mice is altered due to deficiencies in neuronal death during brain development (White et al., 1998; Forger et al., 2004), we generated conditional Bax knock-out mice by crossing floxed Bax mice with a Cre mouse line (T29-1) that expresses Cre recombinase preferentially in CA1 pyramidal neurons after the period of developmental neuronal death. To test whether Bax is indeed knocked out in the CA1 region, we analyzed Bax protein expression in the hippocampus of conditional Bax knock-out mice and their wildtype littermates. In both P20 and 12-week-old mice, Bax protein was reduced in the CA1 region and overlying cortex (Fig. 1A). As Cre recombinase is expressed only in pyramidal neurons of the T29-1 line (Tsien et al., 1996b), residual Bax in these areas is likely expressed by nonpyramidal neurons and glia, but can also result from incomplete knockout in pyramidal neurons. These results confirm that the BAX gene is knocked out in conditional Bax knock-out mice.

To test whether developmental cell death is eliminated in conditional as it is in constitutive Bax knock-out mice, we assessed apoptosis in brain sections of conditional BAX knock-out mice (P1) using TUNEL (an assay for DNA fragmentation resulting from apoptotic cell death). In contrast to no TUNEL labeling in constitutive Bax knock-out mice (White et al., 1998), we observed TUNEL-positive cells in the hippocampus of conditional BAX knock-out mice. The density of TUNEL labeled cells in the CA1 region of conditional knock-out mice was comparable to that of wild-type mice ( $p=0.825$, two-tailed Student's $t$ test; Fig. $1 B, C)$. As constitutive Bax knock-out mice have fewer neurons in their brains (White et al., 1998; Forger et al., 2004), we counted cell numbers using DAPI staining. Cell density in area CA1 was also comparable in conditional Bax knock-out mice and their wild-type littermates ( $p=0.178$, two-tailed Student's $t$ test; Fig. $1 B, D)$. Hence, both developmental cell death and cell number in the CA1 region are intact in conditional Bax knock-out mice.

Our previous study shows that LTD is abolished in constitutive Bax knock-out mice (Jiao and Li, 2011). To test whether conditional Bax knock-out mice also have deficits in synaptic plasticity, we analyzed LTD and LTP in hippocampal slices prepared from these mice (P17-P20). LTD in the CA1 region was induced by stimulating the Schaffer collateral pathway with lowfrequency stimulations ( $1 \mathrm{~Hz}, 900$ pulses), a protocol inducing NMDAR-LTD (Dudek and Bear, 1992). In slices from wild-type littermates of conditional Bax knock-out mice, LTD was effectively induced, as shown by a reduction in the field EPSP $(68.5 \pm$ $4.7 \%$ of baseline at $50-60 \mathrm{~min}$ after stimulation, $n=7$ slices from 4 WT mice; Fig. 2A). However, LTD was blocked in brain slices from Bax conditional knock-out mice (fEPSPs at 50-60 min after stimulation: $100.1 \pm 7.0 \%$ of baseline in slices from knockout mice, $p=0.003$ compared with slices from wild-type mice, $n=8$ slices from $5 \mathrm{KO}$ mice, $F_{(1,13)}=12.992$, one-way ANOVA; Fig. 2A).

LTP was elicited by tetanic stimulation of the Schaffer collateral pathway (two trains of $100 \mathrm{~Hz}, 1 \mathrm{~s}$ stimulation separated by 20 s). Unlike LTD, however, LTP in Bax knock-out and wild-type slices was comparable (fEPSPs at 50-60 min after stimulation: $155.8 \pm 11.3 \%$ of baseline in Bax knock-out slices and $141.1 \pm$ $8.9 \%$ of baseline in wild-type slices, $n=6$ slices from four mice for each group; $F_{(1,10)}=1.033, p=0.33$, one-way ANOVA; Fig. $2 B)$. These results indicate that conditional Bax knock-out mice, 
like constitutive Bax knock-out mice, have LTD impairment, but normal LTP.

\section{Innate fear is intact in Bax knock-out mice}

To assess the locomotion and anxiety-like behavior of CA1-specific Bax knock-out mice, we analyzed them with the open field, light/dark box, and elevated zero maze tests. For the open field test, mice were placed in an empty arena and allowed to freely explore it for $30 \mathrm{~min}$. Mice are naturally fearful of open spaces, and therefore spend more time in the corner than in the central area of the test arena. This avoidance behavior is widely used to assess the anxious state of mice. In addition, the mobility of mice in the test arena reflects their locomotor activity. The total distances traveled by Bax knock-out mice and their wild-type littermates during both the entire test period and each $5 \mathrm{~min}$ of it were indistinguishable $(p=0.601$, two-tailed Student's $t$ test; Fig. 3B: $F_{\text {genotype }} \times_{\text {blocks(5,108) }}=0.154, p=0.978$, two-way ANOVA; Fig. 3A). Likewise, Bax knock-out and wild-type mice also traveled comparable distances in the central area of the arena (Fig. $3 B: p=0.883$, two-tailed Student's $t$ test; Fig. $3 A$ : $F_{\text {genotype }} X_{\text {blocks(5,108) }}=0.023, p=1.000$, two-way ANOVA). These results indicate that the locomotor activity and aversion of open space by Bax knock-out mice are unaffected.

In the light/dark box test, the exploratory activities of the mice stem from their fear of brightly illuminated areas and tendency to explore novel places. Bax knockout and wild-type mice spent comparable amounts of time in the light and dark compartments $(p=0.459$, two-tailed Student's $t$ test; Fig. $3 C$ ). Mice in the elevated zero maze also tend to avoid the open arm and explore new areas. The proportion of time that Bax knock-out and wild-type mice spent in the open and closed arms was indistinguishable $(p=$ 0.328 for open arm, $p=0.378$ for closed arm, two-tailed Student's $t$ test; Fig. 3D). Thus, the exploratory behavior of Bax knock-out mice in the light/dark box and the elevated zero maze test is intact.

Together, results from all three tests consistently show that the anxious state and innate fear are normal in CA1specific Bax knock-out mice.

\section{Depressive behavior is attenuated in Bax knock-out mice} In the adult hippocampus, NMDAR-LTD can be facilitated by stress (Wagner and Alger, 1995; Xu et al., 1997). The function
A

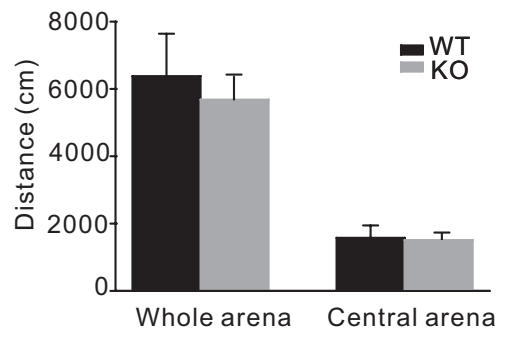

B

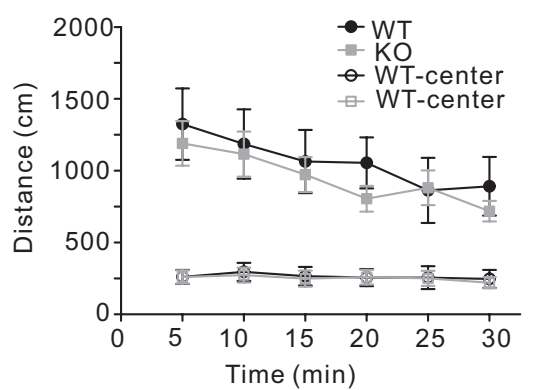

C

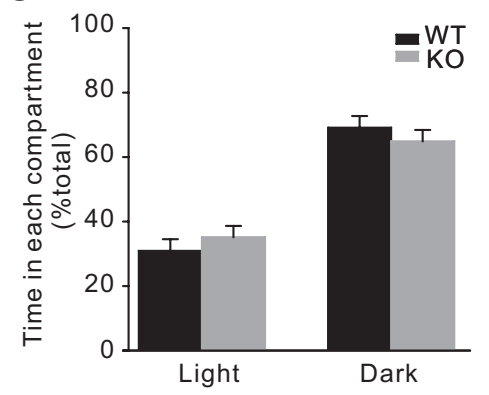

D

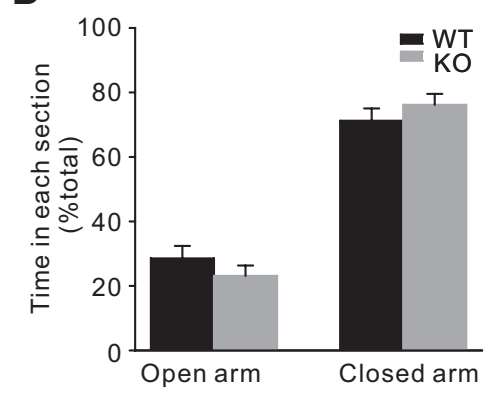

Figure 3. $A-D$, Innate fear and anxiety-like behavior are normal in CA1-specific Bax knock-out mice. Bax knock-out mice, 8-10 weeks old, and their wild-type littermates were used in the open field test $(\boldsymbol{A}, \boldsymbol{B})$, light/dark box test $(\boldsymbol{C})$, and elevated zero maze test (D). $\boldsymbol{A}$, Total distance traveled by Bax knock-out and wild-type mice in the entire text box and the center (one-quarter of the total area around the center of the arena) of the test box during the 30 min open field test. $\boldsymbol{B}$, The distance traveled during each 5 min block of the open field test in the entire arena and the center of the arena. For $\boldsymbol{A}$ and $\boldsymbol{B}$ : WT mice, $n=8 ; \mathrm{K} 0$ mice, $n=12$. $\boldsymbol{C}$, The proportion of time mice spent in the light and dark compartments in the light/dark box test (WT mice, $n=27 ; \mathrm{KO}$ mice, $n=$ 15). D, The proportion of time mice spent in the open and closed arms in the elevated zero maze test (WT mice, $n=12$; K0 mice, $n=8)$. Data are presented as the mean \pm SEM.

A
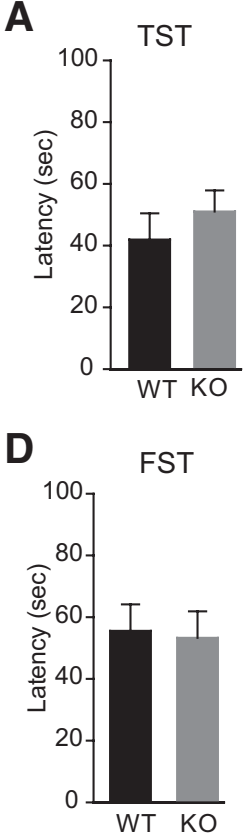

B
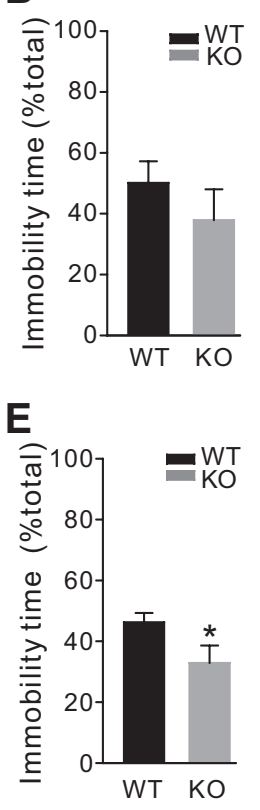

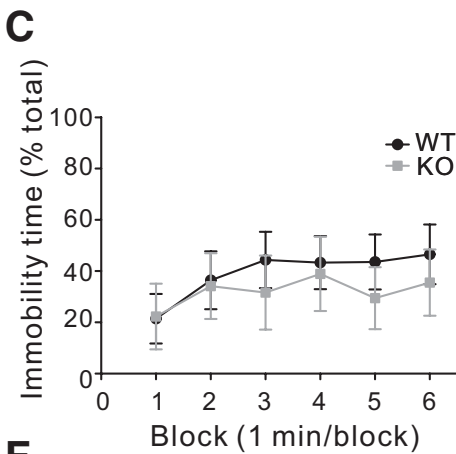

$\mathbf{F}$

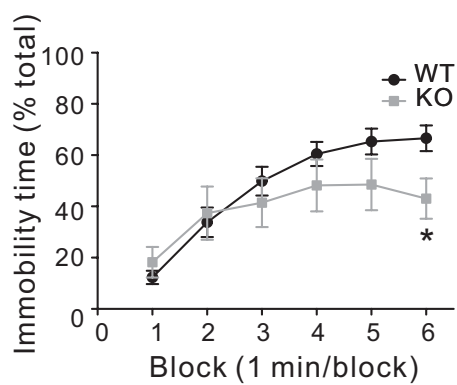

Figure 4. Depressive behavior is suppressed in conditional Bax knock-out mice. $\boldsymbol{A}-\boldsymbol{F}$, Bax knock-out mice, $8-10$ weeks old, and their wild-type littermates were used in the tail suspension $(\boldsymbol{A}-\boldsymbol{C})$ and forced swimming test $(\boldsymbol{D}-\boldsymbol{F})$. $\boldsymbol{A}$, Latency to the first immobility in tali suspension test. $\boldsymbol{B}$, Percentage of immobility time during the $6 \mathrm{~min}$ test period of the tail suspension test. $\boldsymbol{C}$, Percentage of immobility time during each 1 min block of the tail suspension test. For $\boldsymbol{A}-\boldsymbol{C}$ : WT mice, $n=14 ; \mathrm{K} 0$ mice, $n=10$. $\boldsymbol{D}$, Latency to the first immobility in forced swimming test. $\boldsymbol{E}$, Percentage of immobility time during the 6 min test period of the forced swimming test. $F$, Percentage of immobility time during each 1 min block of the forced swimming test. For $\boldsymbol{D}-\boldsymbol{F}$ : WT mice, $n=32 ; \mathrm{KO}$ mice, $n=18$. Data are presented as the mean $\pm \mathrm{SEM}$. ${ }^{*} p<0.05$. 
A

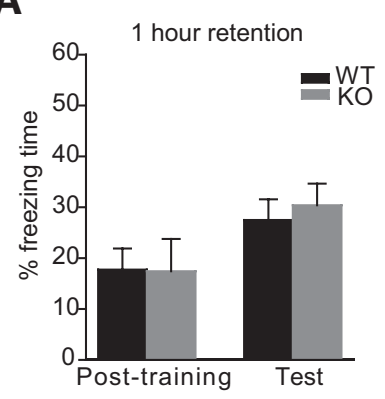

C

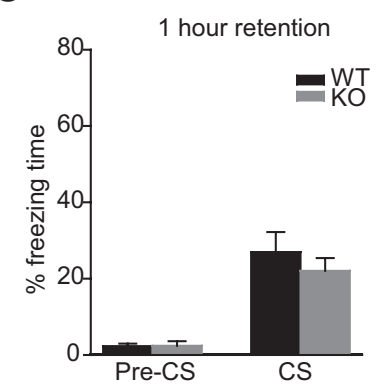

B

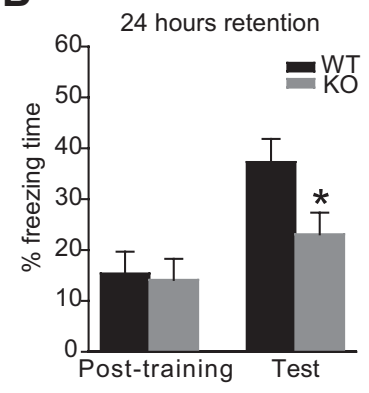

D

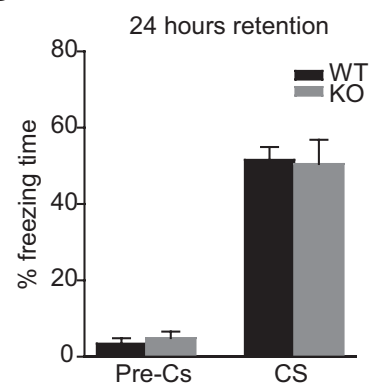

Figure 5. Long-term contextual fear memory is impaired in conditional Bax knock-out mice. Bax knock-out mice, 8-10 weeks old, and their wild-type littermates were used in the fear conditioning test. $A$, Freezing of mice in the training chamber immediately and at $1 \mathrm{~h}$ after fear conditioning (WT mice, $n=20$; KO mice, $n=24$ ). $B$, Contextual fear memory tested at $24 \mathrm{~h}$ after training (WT mice, $n=16$; KO mice, $n=15$ ). $C$, Cued fear memory tested at $1 \mathrm{~h}$ after training (WT mice, $n=10 ; \mathrm{K} 0$ mice, $n=15$ ). $\boldsymbol{D}$, Cued fear memory tested at $24 \mathrm{~h}$ after training (WT mice, $n=20$; KO mice, $n=18$ ). ${ }^{*} p<0.05$. Data are presented as the mean \pm SEM.

of NMDAR-LTD in stress-related psychophysiology, however, is unclear. Since stress is a well recognized predisposing factor for depressive disorders (Lupien et al., 2009), it is possible that NMDAR-LTD plays a role in depressive behavior. To test this possibility, we conducted in CA1-specific Bax knock-out mice the tail suspension and the forced swimming test, two widely used behavioral assays assessing behavioral despair in mice (Porsolt et al., 1977; Steru et al., 1985). In the tail suspension and the forced swimming test, the latency to first immobility was comparable in Bax knock-out and wild-type mice ( $p=0.099$ for TST and $p=$ 0.724 for FST, two-tailed Student's $t$ test; Fig. $4 A, D)$. During the 6 min tail suspension test, while the percentage of immobility duration was less in Bax knock-out mice than in wild-type mice, it was not statistically different between the two groups $(p=$ 0.319 , two-tailed Student's $t$ test; Fig. $4 B$ ). Likewise, the percentage of immobility during each $1 \mathrm{~min}$ block of the test period was also comparable in wild-type and knock-out mice $\left(F_{\text {genotype }} \times\right.$ minute $(5,60)=0.094, p=0.993$, two-way ANOVA; Fig. $4 C)$. In the forced swimming test, however, Bax knock-out mice displayed significantly less total immobility during the entire 6 $\min (p=0.029$, two-tailed Student's $t$ test; Fig. $4 E)$. This decrease in immobility primarily took place during the last minute of the test $(p=0.014$, two-tailed Student's $t$ test; Fig. $4 F)$. These results suggest that behavioral despair is suppressed in CA1-specific Bax knock-out mice.

Long-term contextual fear memory is impaired in CA1specific Bax knock-out mice

To test the role of NMDAR-LTD in fear memory, we conducted the contextual and the cued fear conditioning test (two paradigms eliciting associative fear memory) in CA1-specific Bax

knock-out mice and their wild-type littermates. Mice were placed in the test chamber, and were allowed to freely explore the chamber for $2 \mathrm{~min}$ before receiving the coterminated conditioned (tone) and unconditioned stimuli (electrical footshock). During the 2 min prestimulation period, the freezing time was indistinguishable in wild-type mice $(2.58 \pm 1.30 \%)$ and Bax conditional knock-out mice $(1.84 \pm 0.86 \% ; p=0.70$, compared with wildtype mice using the two-tailed Student's $t$ test), suggesting that they had comparable anxiety levels in a novel environment. Freezing immediately after associative training was comparable in Bax knock-out and wild-type mice ( $p=0.815$, Kruskal-Wallis one-way ANOVA on ranks; Fig. $5 A$ ), suggesting that Bax knockout mice have intact sensory function, fear response, and associative fear learning. To assess short-term memory, mice were tested in the training context at $1 \mathrm{~h}$ after fear conditioning. Bax knockout and wild-type mice exhibited similar levels of freezing ( $p=$ 0.630, two-tailed Student's $t$ test; Fig. $5 A$ ), indicating that Bax knock-out mice have normal short-term contextual fear memory.

To test long-term associative fear memory, a different cohort was trained and at $24 \mathrm{~h}$ after fear conditioning was tested for freezing in the training context (for contextual fear memory) or in a novel context in the presence of tones (for cued fear memory). Bax knock-out mice froze less often in the training context than wild-type mice ( $p=0.030$, two-tailed Student's $t$ test; Fig. $5 B)$. By contrast, freezing during both the pretone and the tone period in a novel context at 1 or $24 \mathrm{~h}$ after training was comparable in Bax knock-out and wild-type mice ( $p=0.415$ for $1 \mathrm{~h}, p=$ 0.927 for $24 \mathrm{~h}$, two-tailed Student's $t$ test; Fig. $5 C, D)$. These results indicate that CA1-specific Bax knock-out mice are specifically impaired in long-term contextual, but not cued or short-term, contextual fear memory.

Together, our results of the fear conditioning test indicate that Bax is required for consolidation, but not acquisition of fear memory.

\section{LTD induced by fear conditioning is abolished in conditional Bax knock-out mice}

Synaptic plasticity is an important cellular mechanism that underlies learning and memory. Since Bax is required for the induction of NMDAR-LTD, the fear memory defect of BAX knock-out mice might be due to their LTD impairment. To test this possibility, we first examined whether LTD is associated with the fear conditioning paradigm. We prepared hippocampal slices from adult mice (7-9 weeks old) and induced LTD in the CA1 region by stimulating the Schaffer collateral pathway with lowfrequency stimulations ( $1 \mathrm{~Hz}, 900$ pulses). In hippocampal slices of naive wild-type mice (without fear conditioning), lowfrequency stimulation had no effect on fEPSPs $(98.5 \pm 6.4 \%$ of prestimulation baseline at 50-60 min after stimulation; $p=0.69$, compared with prestimulation baseline, Kruskal-Wallis one-way ANOVA on ranks; $n=5$ slices from three animals; Fig. $6 A$ ). This is consistent with previous reports that, unlike in brains of juvenile mice, LTD is not readily induced by low-frequency stimulation in the hippocampus of adult animals (Rosenzweig and Barnes, 2003). In hippocampal slices from wild-type mice subjected to fear conditioning, however, low-frequency stimulation caused a decrease in fEPSPs $(73.5 \pm 6.2 \%$ of prestimulation baseline at 50-60 min after stimulation; $p=0.006$ compared with prestimulation baseline, Kruskal-Wallis oneway ANOVA on ranks, $F_{(1,15)}=5.642 ; p=0.031$, compared with fEPSPs at 50-60 min after stimulation in naive slices, one-way ANOVA; $n=12$ slices from eight fear-conditioned 
wild-type mice; Fig. 6A). These results indicate that fear conditioning facilitates LTD induction.

Next, we analyzed LTD in conditional Bax knock-out mice subjected to fear conditioning. In contrast to hippocampal slices from wild-type mice, low-frequency stimulation induced no LTD in hippocampal slices taken from Bax knockout mice (105 $\pm 8.6 \%$ of prestimulation baseline at $50-60 \mathrm{~min}$ after stimulation; $p=0.442$, compared with prestimulation baseline; $p=0.596$, compared with fEPSPs in naive wild-type slices and $p=$ 0.017, compared to that in fearconditioned wild-type mice at 50-60 $\mathrm{min}$ after stimulation, one-way ANOVA; $n=8$ slices from five Bax knock-out animals; Fig. 6A). The LTD impairment in conditional Bax knock-out mice is not caused by defective basal synaptic transmission, as the input-output relationship, pairedpulse ratio, and LTP in the CA1 region were all comparable in wild-type and knock-out mice (Fig. 6B-D).

Together, these findings show that fear conditioning-facilitated LTD is obliterated in conditional Bax knock-out mice. Hence, the fear memory deficit in BAX knock-out mice might be attributed to their LTD impairment.

\section{Discussion}

In this study, we investigated the role of NMDAR-LTD in fear memory using transgenic mice impaired in NMDAR-LTD in the CA1 region. Our results show that NMDAR-LTD in the hippocampus is required for consolidation of, but not for the acquisition of, fear memory. In addition, our behavioral tests suggest that Bax in the hippocampal CA1 region contributes to depressive behavior.

NMDAR-LTD has been implicated in several forms of memory. Mice lacking NMDAR-LTD due to inhibition or deletion of key molecules required for LTD induction are impaired in working memory, spatial memory, and behavioral flexibility (Ge et al., 2010; Kim et al., 2011), but not the acquisition of discriminative learning (Dalton et al., 2011). The role of NMDAR-LTD in fear memory, however, is poorly understood. Aberrant fear memory is a core symptom of many psychiatric disorders including posttraumatic stress disorder and phobia (Parsons and Ressler, 2013). In this study, we used pavlovian fear conditioning, both contextual and cued, to induce fear memory in CA1-specific Bax knockout mice.

The establishment of contextual fear memory requires mice to remember the context in which they receive adverse stimuli, and is dependent on the hippocampus (Davis, 1986; Phillips and LeDoux, 1992; Kim and Jung, 2006; Biedenkapp and Rudy, 2007). By contrast, cued fear memory does not require the hippocampus, and is dependent on other brain regions such as the amygdala (Kim and Jung, 2006). Our behavioral tests show that contextual fear memory is impaired in CA1-specific Bax knockout mice, but cued fear memory is unaffected. This result is consistent with the fact that Bax expression is knocked out only in the hippocampus, but not in the amygdala, as the CA1 Cre line we
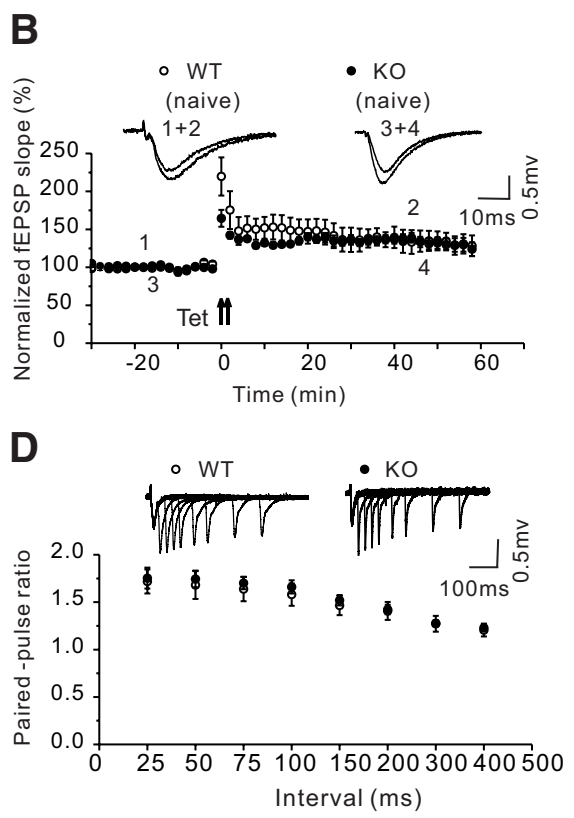

Figure 6. Fear conditioning-facilitated LTD is impaired in adult conditional Bax knock-out mice. Hippocampal slices were slices from three naive wild-type mice; $n=12$ slices from eight fear-conditioned wild-type mice; $n=8$ slices from five

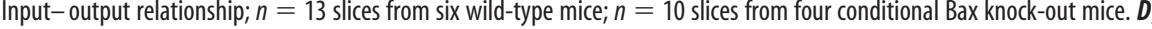
Paired-pulse ratio; $n=11$ slices from six wild-type; and $n=11$ slices from four conditional Bax knock-out mice. Data are presented as the mean \pm SEM. FC, Fear conditioning.

used to generate the conditional Bax knock-out mice expresses Cre recombinase preferentially in the CA1 region (Tsien et al., 1996b). In our 12-week-old conditional knock-out mice, in addition to the CA1 region, Bax expression is also greatly reduced in the dentate gyrus. The behavioral phenotypes of conditional Bax knock-out mice, therefore, could also be attributed to Bax loss in the dentate gyrus.

As our electrophysiology study found that NMDAR-LTD in CA1 neurons is abolished in conditional Bax knock-out mice, the impairment of contextual fear memory is likely due to the LTD deficit. By analyzing different stages of memory, moreover, we determined that in Bax knock-out mice, the impairment in consolidation, but not acquisition, is responsible for defective fear memory. This finding is consistent with the previous report that NMDAR-LTD is required for the consolidation of, but not acquisition of, spatial memory (Ge et al., 2010). Hence, it appears that LTD is a cellular mechanism underlying the consolidation of multiple forms of memory. However, it has been reported (Zeng et al., 2001) that LTD is impaired in calcineurin knock-out mice, while contextual fear memory is normal in these mice. This discrepancy could be caused by different strengths of fear conditioning used in our study and the study by Zeng et al. (2001). Zeng et al. (2001) used three shock-tone pairs for fear conditioning, while only one pair was used in our study. The strong training protocol in the study by Zeng et al. (2001) could have saturated fear memory, and therefore mitigated the difference between the knock-out and wild-type mice. In fact, in the study by Zeng et al. (2001), calcineurin knock-out mice froze less often than wild-type mice in the test for contextual fear memory retention, but the difference in freezing time did not reach statistical significance. 
It is thought that Bax promotes apoptosis in the CNS in psychiatric diseases, such as depression. We found that Bax deletion in the CA1 region leads to attenuation of depressive behavior. Given defective LTD in Bax knock-out mice, it is possible that the nonapoptotic function of Bax in LTD contributes to depressive behavior and the pathophysiology of depression. In fact, this scenario is supported by the facts that both acute and chronic stress facilitate hippocampal LTD, and that this facilitation can be inhibited by the antidepressant fluvoxamine (Xu et al., 1997; Yang et al., 2005; Holderbach et al., 2007; Wong et al., 2007).

Bax conditional knock-out mice display less behavioral despair in the forced swimming test, but their immobility in the closely related tail suspension test is not significantly changed. Although the forced swimming and the tail suspension test are conceptually similar and both measure behavioral despair, it appears that they have different neuronal mechanisms, as they are controlled by different genes and neurotransmitters (Yoshikawa et al., 2002; Chatterjee et al., 2012). Hence, it is possible that they have different sensitivities to LTD impairment.

How does LTD contribute to memory consolidation? Memory formation requires strengthening of a subset of synapses (Leuner et al., 2003; Roberts et al., 2010), which may take place at the expense of weakening some other synapses to keep the overall synaptic strength in neurons consistent. Alternatively, memory consolidation may need the LTD mechanism to modify the hippocampal circuit for the storage of fear memory. These are intriguing questions for future research.

\section{References}

Bear MF, Malenka RC (1994) Synaptic plasticity: LTP and LTD. Curr Opin Neurobiol 4:389-399. CrossRef Medline

Biedenkapp JC, Rudy JW (2007) Context preexposure prevents forgetting of a contextual fear memory: implication for regional changes in brain activation patterns associated with recent and remote memory tests. Learn Mem 14:200-203. CrossRef Medline

Brigman JL, Wright T, Talani G, Prasad-Mulcare S, Jinde S, Seabold GK, Mathur P, Davis MI, Bock R, Gustin RM, Colbran RJ, Alvarez VA, Nakazawa K, Delpire E, Lovinger DM, Holmes A (2010) Loss of GluN2B-containing NMDA receptors in CA1 hippocampus and cortex impairs long-term depression, reduces dendritic spine density, and disrupts learning. J Neurosci 30:4590-4600. CrossRef Medline

Chatterjee M, Jaiswal M, Palit G (2012) Comparative evaluation of forced swim test and tail suspension test as models of negative symptom of schizophrenia in rodents. ISRN Psychiatry 2012:595141. CrossRef Medline

Collingridge GL, Peineau S, Howland JG, Wang YT (2010) Long-term depression in the CNS. Nat Rev Neurosci 11:459-473. CrossRef Medline

Dalton GL, Ma LM, Phillips AG, Floresco SB (2011) Blockade of NMDA GluN2B receptors selectively impairs behavioral flexibility but not initial discrimination learning. Psychopharmacology (Berl) 216:525-535. CrossRef Medline

Davis M (1986) Pharmacological and anatomical analysis of fear conditioning using the fear-potentiated startle paradigm. Behav Neurosci 100:814824. CrossRef Medline

Djordjevic A, Djordjevic J, Elaković I, Adzic M, Matić G, Radojcic MB (2012) Fluoxetine affects hippocampal plasticity, apoptosis and depressive-like behavior of chronically isolated rats. Prog Neuropsychopharmacol Biol Psychiatry 36:92-100. CrossRef Medline

Dudek SM, Bear MF (1992) Homosynaptic long-term depression in area CA1 of hippocampus and effects of N-methyl-D-aspartate receptor blockade. Proc Natl Acad Sci U S A 89:4363-4367. CrossRef Medline

Forger NG, Rosen GJ, Waters EM, Jacob D, Simerly RB, de Vries GJ (2004) Deletion of Bax eliminates sex differences in the mouse forebrain. Proc Natl Acad Sci U S A 101:13666-13671. CrossRef Medline

Ge Y, Dong Z, Bagot RC, Howland JG, Phillips AG, Wong TP, Wang YT (2010) Hippocampal long-term depression is required for the consolidation of spatial memory. Proc Natl Acad Sci U S A 107:16697-16702. CrossRef Medline
Holderbach R, Clark K, Moreau JL, Bischofberger J, Normann C (2007) Enhanced long-term synaptic depression in an animal model of depression. Biol Psychiatry 62:92-100. CrossRef Medline

Jiao S, Li Z (2011) Nonapoptotic function of BAD and BAX in long-term depression of synaptic transmission. Neuron 70:758-772. CrossRef Medline

Kim JI, Lee HR, Sim SE, Baek J, Yu NK, Choi JH, Ko HG, Lee YS, Park SW, Kwak C, Ahn SJ, Choi SY, Kim H, Kim KH, Backx PH, Bradley CA, Kim E, Jang DJ, Lee K, Kim SJ, et al. (2011) PI3Kgamma is required for NMDA receptor-dependent long-term depression and behavioral flexibility. Nat Neurosci 14:1447-1454. CrossRef Medline

Kim JJ, Jung MW (2006) Neural circuits and mechanisms involved in Pavlovian fear conditioning: a critical review. Neurosci Biobehav Rev 30: 188-202. CrossRef Medline

Leuner B, Falduto J, Shors TJ (2003) Associative memory formation increases the observation of dendritic spines in the hippocampus. J Neurosci 23:659-665. Medline

Li Z, Jo J, Jia JM, Lo SC, Whitcomb DJ, Jiao S, Cho K, Sheng M (2010) Caspase-3 activation via mitochondria is required for long-term depression and AMPA receptor internalization. Cell 141:859-871. CrossRef Medline

Lupien SJ, McEwen BS, Gunnar MR, Heim C (2009) Effects of stress throughout the lifespan on the brain, behaviour and cognition. Nat Rev Neurosci 10:434-445. CrossRef Medline

Malenka RC, Bear MF (2004) LTP and LTD: an embarrassment of riches. Neuron 44:5-21. CrossRef Medline

Manji H, Kato T, Di Prospero NA, Ness S, Beal MF, Krams M, Chen G (2012) Impaired mitochondrial function in psychiatric disorders. Nat Rev Neurosci 13:293-307. CrossRef Medline

Nicholls RE, Alarcon JM, Malleret G, Carroll RC, Grody M, Vronskaya S, Kandel ER (2008) Transgenic mice lacking NMDAR-dependent LTD exhibit deficits in behavioral flexibility. Neuron 58:104-117. CrossRef Medline

Oltvai ZN, Milliman CL, Korsmeyer SJ (1993) Bcl-2 heterodimerizes in vivo with a conserved homolog, Bax, that accelerates programmed cell death. Cell 74:609-619. CrossRef Medline

Parsons RG, Ressler KJ (2013) Implications of memory modulation for post-traumatic stress and fear disorders. Nat Neurosci 16:146-153. CrossRef Medline

Phillips RG, LeDoux JE (1992) Differential contribution of amygdala and hippocampus to cued and contextual fear conditioning. Behav Neurosci 106:274-285. CrossRef Medline

Porsolt RD, Le Pichon M, Jalfre M (1977) Depression: a new animal model sensitive to antidepressant treatments. Nature 266:730-732. CrossRef Medline

Roberts TF, Tschida KA, Klein ME, Mooney R (2010) Rapid spine stabilization and synaptic enhancement at the onset of behavioural learning. Nature 463:948-952. CrossRef Medline

Rosenzweig ES, Barnes CA (2003) Impact of aging on hippocampal function: plasticity, network dynamics, and cognition. Prog Neurobiol 69: 143-179. CrossRef Medline

Rudy JW, Sutherland RJ (2008) Is it systems or cellular consolidation? Time will tell. An alternative interpretation of the Morris group's recent science paper. Neurobiol Learn Mem 89:366-369. CrossRef Medline

Steru L, Chermat R, Thierry B, Simon P (1985) The tail suspension test: a new method for screening antidepressants in mice. Psychopharmacology (Berl) 85:367-370. CrossRef Medline

Takeuchi O, Fisher J, Suh H, Harada H, Malynn BA, Korsmeyer SJ (2005) Essential role of BAX, BAK in B cell homeostasis and prevention of autoimmune disease. Proc Natl Acad Sci U S A 102:11272-11277. CrossRef Medline

Teyler TJ, Rudy JW (2007) The hippocampal indexing theory and episodic memory: updating the index. Hippocampus 17:1158-1169. CrossRef Medline

Tsien JZ, Chen DF, Gerber D, Tom C, Mercer EH, Anderson DJ, Mayford M, Kandel ER, Tonegawa S (1996a) Subregion- and cell type-restricted gene knockout in mouse brain. Cell 87:1317-1326. CrossRef Medline

Tsien JZ, Huerta PT, Tonegawa S (1996b) The essential role of hippocampal CA1 NMDA receptor-dependent synaptic plasticity in spatial memory. Cell 87:1327-1338. CrossRef Medline

Wagner JJ, Alger BE (1995) GABAergic and developmental influences on 
homosynaptic LTD and depotentiation in rat hippocampus. J Neurosci 15:1577-1586. Medline

White FA, Keller-Peck CR, Knudson CM, Korsmeyer SJ, Snider WD (1998) Widespread elimination of naturally occurring neuronal death in Baxdeficient mice. J Neurosci 18:1428-1439. Medline

Wolter KG, Hsu YT, Smith CL, Nechushtan A, Xi XG, Youle RJ (1997) Movement of Bax from the cytosol to mitochondria during apoptosis. J Cell Biol 139:1281-1292. CrossRef Medline

Wong TP, Howland JG, Robillard JM, Ge Y, Yu W, Titterness AK, Brebner K, Liu L, Weinberg J, Christie BR, Phillips AG, Wang YT (2007) Hippocampal long-term depression mediates acute stress-induced spatial memory retrieval impairment. Proc Natl Acad Sci U S A 104:1147111476. CrossRef Medline

Xin M, Deng X (2006) Protein phosphatase 2A enhances the proapoptotic function of Bax through dephosphorylation. J Biol Chem 281:1885918867. CrossRef Medline
Xu L, Anwyl R, Rowan MJ (1997) Behavioural stress facilitates the induction of long-term depression in the hippocampus. Nature 387:497-500. CrossRef Medline

Yang CH, Huang CC, Hsu KS (2005) Behavioral stress enhances hippocampal CA1 long-term depression through the blockade of the glutamate uptake. J Neurosci 25:4288-4293. CrossRef Medline

Yoshikawa T, Watanabe A, Ishitsuka Y, Nakaya A, Nakatani N (2002) Identification of multiple genetic loci linked to the propensity for "behavioral despair" in mice. Genome Res 12:357-366. CrossRef Medline

Zeng H, Chattarji S, Barbarosie M, Rondi-Reig L, Philpot BD, Miyakawa T, Bear MF, Tonegawa S (2001) Forebrain-specific calcineurin knockout selectively impairs bidirectional synaptic plasticity and working/episodiclike memory. Cell 107:617-629. CrossRef Medline

Zlatković J, Filipović D (2012) Bax and B-cell-lymphoma 2 mediate proapoptotic signaling following chronic isolation stress in rat brain. Neuroscience 223:238-245. CrossRef Medline 